\title{
Een frase, verskeie sake
}

Onlangs lees ek die volgende frase in 'n langer sin raak: “... enige terrein van die onderwys (vanaf vroeë-kind-onderwysvlak tot tersiêre onderwysvlak)"; dit is die gedeelte tussen hakies wat tot onderstaande bespreking gelei het.

As ek daardie gedeelte in Engels moes vertaal, sou dit waarskynlik "from early childhood education level to tertiary education level" wees. Koppeltekengebruik in Engels verskil in groot mate van dié van Afrikaans. Hoewel dit geen wet van Mede en Perse is nie, is daar tog 'n tendens om 'n koppelteken te plaas tussen kombinasies soos "early + childhood" en "tertiary + education" wanneer daardie kombinasie 'n volgende selfstandige naamwoord bepaal - hier "level". My eie voorkeur sou dus wees: "from early-childhood education level to tertiaryeducation level".

Drie sake in die betrokke frase interesseer my: vertaling, die Afrikaanse spelreëls en idiomatiese Standaardafrikaans.

\section{VERTALING}

Die vertaling van "childhood" is dikwels problematies. Daar is verskillende moontlikhede, soos kinderjare, kindertyd en kleintyd (laasgenoemde 'n bietjie informeel), of net die verbindingsvorm kinder-, byvoorbeeld in verbindings soos kindersiektes, kinderbehoeftes, kinderontwikkeling. Vir my is kinderjare hier die beste oplossing.

Maar wat gemaak met "early-childhood education"? Myns insiens is kindonderwys hoogs onidiomatiese Afrikaans, en kinderonderwys, hoewel volkome idiomaties, laat weer betekenismoontlikhede toe wat nie klop met "early-childhood education" nie. Laasgenoemde word gewoonlik gedefinieer as onderwys vir kinders van tot so agt, nege jaar oud. Kinderonderwys kan klaarblyklik heelwat ouer kinders insluit. 'n Moontlikheid is dus vroeë kinderonderwys.

Die Teaching dictionary of education van prof. AJ Smit (hoofred.; Pretoria: Privaat uitgegee, 2008) vertaal "early childhood" met kleinkinderskap, wat teoreties seker moontlik is, maar vir my is kleinkind en kleinkinder- te naby aan "grandchild(ren)" en dus te geredelik oop vir wanvertolking. Ook kindskap sal nie regtig in so 'n verbinding deug nie, want dié word hoofsaaklik in religieuse of figuurlike verband gebruik. Dalk kan die koppeltekens in iets soos klein-kind-onderwys'n ander betekenis suggereer, maar die kans is skraal.

'n Vertaalwebwerf van die EU gee in Nederlands naas onder meer "onderwijs voor jonge kinderen" ook "voorschools onderwijs", maar laasgenoemde stem nie ooreen met die definisie wat ons Departement van Basiese Onderwys gebruik nie. Skynbaar vermy Nederlands dit om 'n konstruksie op die patroon van "early childhood education" te probeer maak en stel dit eerder idiomaties om.

Indien 'n eenwoordterm of dieselfde volgorde as Engels eenvoudig móét, sou my keuse vroeëkinderjareonderwys(vlak) wees. Dié soort samestelling probeer ek egter vermy waar ek kan.

\section{SPELRË̈L}

Hoekom het ek vroeë kinderonderwys hier bo twee woorde geskryf, maar vroeëkinderjareonderwysvlak een woord? Dit hang af van waarop vroeë betrekking het; in die eerste geval 
slaan vroeë op onderwys (dus 'vroeë onderwys vir kinders'), en in die tweede slaan dit op kinderjare - dus 'die vlak van onderwys vir/in die vroeë kinderjare'.

Hier is een van die Afrikaanse spelreëls ter sprake wat die meeste probleme vir Afrikaansskrywendes oplewer (benewens die blote vas skryf van samestellings!), naamlik die skryfwyse van die sogenaamde samestellende samestellings (reëls 12.6 en 15.27 in die 2017$A W S$ ). Dit is samestellings wat bestaan uit (b.nw./telw. + s.nw. $)^{1}+$ s.nw., waar die (b.nw./telw. + s.nw.) gesamentlik op die laaste s.nw. slaan. Hier bo het ek so 'n samestelling gebruik, naamlik eenwoordterm, want die bedoeling is ' $\mathrm{n}$ term wat uit een woord bestaan', nie 'een term wat 'n woord is' nie. Nog een is vastetermynbelegging: 'belegging vir 'n vaste termyn' - een slaan op woord, vaste slaan op termyn.

Dit verduidelik waarom vroeëkindonderwys nie deug nie (afgesien daarvan dat -kind- in plaas van -kinder- ongewoon is), want dit beteken 'onderwys vir'n vroeë kind of vroeë kinders', wat weer die vraag laat ontstaan of dit 'n kind is wat 'n premature baba was of aangekom het voordat die ouers getroud is of dalk selfs vroeg by die skool aangekom het. Klaarblyklik nie, want dit klop glad nie met "early childhood" nie.

As 'n mens egter "childhood" vertaal met kinderjare, dan is dit vroeëkinderjareonderwys, want dit is 'onderwys in/vir die vroeë kinderjare'. Om dieselfde rede behoort dit myns insiens ook tersiêreonderwysvlak te wees, want dit is in die eerste plek "tersiêre onderwys", selfs al is "tersiêre vlak" miskien denkbaar.

\section{IDIOOM}

Laastens die kwessie van idioom of idiomatiese Standaardafrikaans. Die eerste punt is dat ons te maklik geneig is om (in vertaling) die Engelse patroon te wil volg. In Engels is dit moontlik (hoewel nie altyd goeie styl nie) om 'n rits woorde tot'n samestelling aaneen te strengel (al skryf Engels so 'n "compound" nie vas nie). Vanweë Afrikaans (en Nederlands en Duits) se tradisie om samestellings vas te skryf, word dit bitter moeilik, indien nie onmoontlik nie, om altyd dieselfde aantal woorde in dieselfde volgorde as Engels in 'n enkele samestelling in te ryg.

In die meeste gevalle - nie altyd nie, maar meestal - is dit vir leser en skrywer beter om 'n omstelling te gebruik, soos wat Nederlands doen in die voorbeeld hier bo. Bowendien is dit juis die gewone leser en skrywer wat skop teen sulke ellelange vreemde of ongewone samestellings. Hulle wil eenvoudig nie opvoedkundigesielkundestudente of statistieseberekeningsprogrammatuur skryf óf lees nie.

Ten slotte: Hoewel daar niks verkeerd is met die voorsetsel vanaf nie, is die kombinasie daarvan met tot stilisties en idiomaties nie aan te beveel nie. Vanaf dui die beginpunt van iets aan - tyd, plek of getalle. Dikwels is bloot van genoeg, en dikwels kan dit geskei word tot van ... af.

Vir my sou "van die vlak van onderwys in die vroeë kinderjare tot die vlak van tersiêre onderwys" of net "van vroeëkinderjareonderwys tot tersiêre onderwys" die bevredigendste weergawe van die "probleemfrase" wees wat vertaling, spelling en idioom betref.

\section{JD (ToM) McLachlan}

E-pos: tommcl@whalemail.co.za

b.nw. 'byvoeglike naamwoord'; telw. 'telwoord'; s.nw. 'selfstandige naamwoord'. 